\title{
電力ケーブルの部分放電発生位置標定法の開発
}

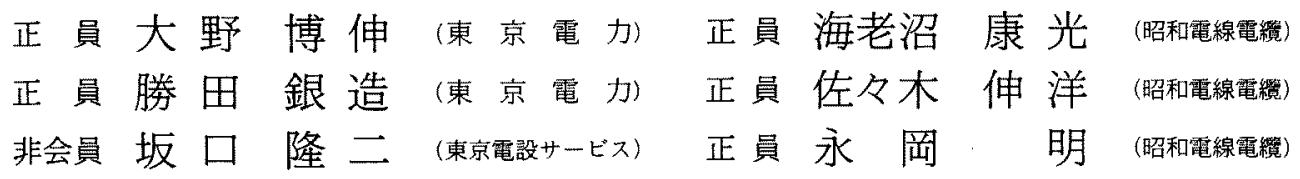

\section{Development of Partial Discharge Location Method of Power Cable}

Hironobu Ohno, Member, Ginzou Katsuta, Member (Tokyo Electric Power Company), Ryuji Sakaguchi, Non-member (Tokyo Densetsu Services Co., Ltd.), Yasumitsu Ebinuma, Member, Nobuhiro Sasaki, Member, Akira Nagaoka, Member (Showa Electric Wire \& Cable Co., Ltd.)

Insulation deterioration of power cable can be measured by the method of partial discharge. If a large partial discharge is detected in a cable, the cable is concluded to be defective and a partial discharge is located to find the position of the defect. However partial discharge location methods have generally disadvantages that they require much skill for operation and are inferior sensitivity and accuracy.

To solve these problems, we have developed a locating method using two-phase cable and an automatic partial discharge locator which automatically localizes the generating site of discharge immediately after making partial discharge measurement by simple operations. We have made field measurements on SL (separately lead-coverd) cables and other cables with the locator in order to test its accuracy and reliability, and it was found that the device is effective and useful.

キーワード：電カケーブル, 部分放電, 位置標定, 自動化, 絶縁劣化診断

\section{1.まえがき}

電力を安定に供給するため, 既設電力ケーブルの絶 緑破壞事故を未然に防止することは重要である。この ために絶緑少化診断が害施されており，その一つに部 分放電測定がある。この測定で大きな部分放電が測定 されると，その線路は「不良」または「要注意」と判 断される。そして次に，どの位置から部分放電が発生 しているか，すなわち位置標定が必要となる。その発 生位置を検討し，修復または引換えが行われる。

従来から部分放電位置標定は行われていたが,

（i）熟練した技術が必要である

（ii）測定の感度や精度が悪い

などの欠点があった。そこで, これらの欠点を解消す るため, 部分放電の位置標定法を開発すると共に, 自 動位置標定器の開発を行った ${ }^{(1)}$ 。自動標定器はディジ タルメモリー, マイクロコンピュータおよびプリンタ
から構成され，簡単な操作で測定後ただちに発生位置 を知ることができる。

開発した自動標定器の測定精度と信頼性の確認を行 うために模擬線路で実験を行い，良好な結果を得た。 また，現場測定にも用い，その測定精度を確認すると 共に, 部分放電が多数発生しているケーブル部を撤去 し，確認試験を行った。

\section{2. 従来の測定法とその欠点}

従来の部分放電位置標定の測定回路を図 1 に示す。 被測定ケーブルの測定端に結合コンデンサおよび検出 器を取付け，高電圧を印加する。ケーブルで発生した 部分放電パルスは, 検出器で検出され, 増幅された後 オシロスコープ上に, 図 2 に示すような波形として現 れる。このオシロスコープ上の図 2 に示した第 1 波と 第 2 波の時間差 $T$ を計測し，これを(1) 式に代入し, 位置を算出している(2)。 


$$
X=L-\frac{V_{p} \times T}{2}
$$

ここに, $V_{p}:$ 伝搬速度

更に，部分放電の発生䇢所は 1 箇所に集中している わけではなく、複数䇢所に分散している場合があるの で,どの位置からの発生が多いかなどの統計処理を行 っている。

しかし，前述の従来の測定法には次のような欠点が あり，位置標定の実施を難しくしている。

（i）波形解析後の位置計算および統計処理に時間 がかかる。

（ii）雑音の影響で高感度検出が難しい。

(iii） ジョイントの影響で測定誤差を生じることが ある。

（iv）伝搬によるパルス波高值の減衰で検出感度が 低下する。

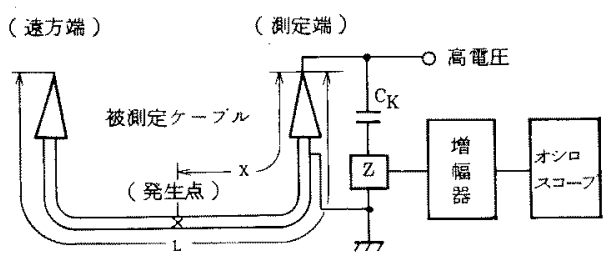

$C_{K}:$ 結合コンデンサ, $z:$ 検出器

図 1 従来の部分放電発生位置測定法

Fig. 1. Conventional circuit for partial discharge measurement.

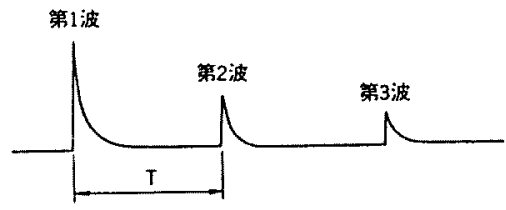

図 2 測定端で観測される波形

Fig. 2. Typical pulse waveform observed at measuring termination.

\section{3. 部分放電位置標定法の開発}

今回開発した部分放電位置標定法を図 3 に示す。 この位置標定法は従来の欠点に対して表 1 に示す対 策を施している。その詳細は次のと扔りである。

\section{〈3.1〉 位置標定器の自動化}

(1) 構成と機能自動標定器はディジタルメモ リー, マイクロコンピュータおよびプリンタから構成 されている。その外観を図 4 に示す。自動標定器は測 定車に搭載されている。

波形観測には高速処理可能なディジタルメモリーを 採用しこのディジタルメモリーから順次送られてく る波形から，パルスの到達時間差を計算し，(1)式の 計算を実行する。また，測定時間内に多数取入れられ た部分放電の発生位置とその頻度の統計処理（頻度グ ラフの作成）を行いプリントアウトする。なお，端末 部からパルスを注入し，伝搬速度 $V_{p}$ を測定する。

（2）パルスの時間差の測定 パルスの立上り点 を正確に読取ることは位置標定を行ううえで重要であ るが, 雑音による基線の乱れや，パルスの波形ひずみ により，正確に読取ることは難しい。測定者がパルス 波形写真より立上り点を読取る場合は，パルスの立上 りスロープを延長し，基線と交わる点を立上り点とす ることで，これらの影響を少なくできる。マイクロコ ンピュータによる立上り点の読取りにおいても, 測定

表 1 開発内容

Table 1. Developed items.

\begin{tabular}{|c|c|c|c|}
\hline \multicolumn{2}{|r|}{ 問題となる項目 } & \multicolumn{2}{|l|}{ 策 } \\
\hline (1) & 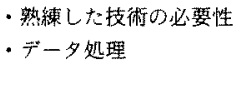 & $\begin{array}{l}\text { ・マイクロコンピュータに } \\
\text { よる計算 } \\
\text { ・ブリンタによる出力 }\end{array}$ & $\begin{array}{l}\text { 自動標 } \\
\text { 定器の } \\
\text { 開発 }\end{array}$ \\
\hline (2) & - 雑音対策 & \multicolumn{2}{|c|}{ ・位相調整による正弦波／イズ除去 } \\
\hline (3) & ・ジョイントによる影箇 & \multicolumn{2}{|c|}{$\begin{array}{l}\text { ・三相ケープルのうちの二相を測定 } \\
\text { に用いた新方式の開発 }\end{array}$} \\
\hline (4) & ・パルス減衰 & \multicolumn{2}{|l|}{ ・遠力端への增幅器の設㯰 } \\
\hline
\end{tabular}

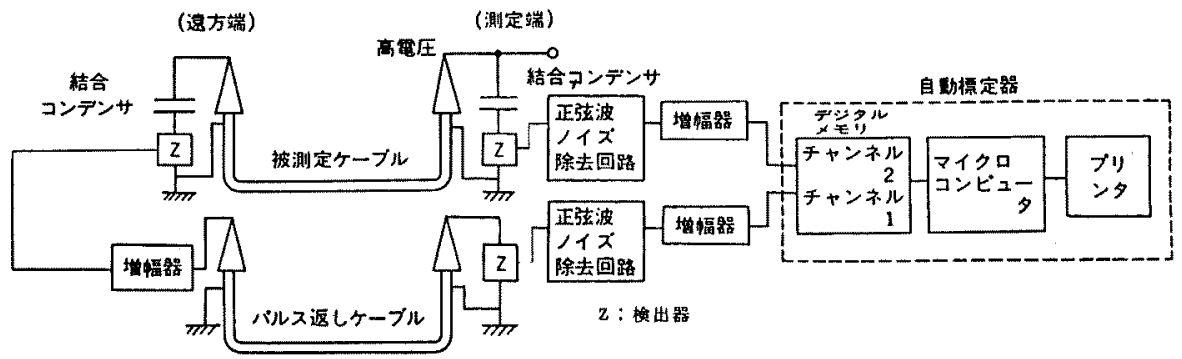

図 3 開発した部分放電位置標定法

Fig. 3. Developed method of partial discharge location. 


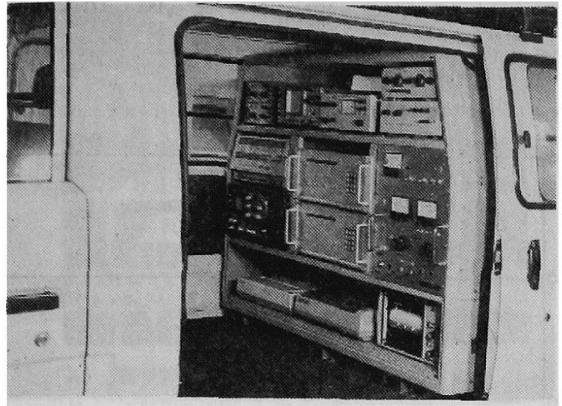

図 4 自動標定器の外観

Fig. 4. Appearance of the automatic partial discharge locator.

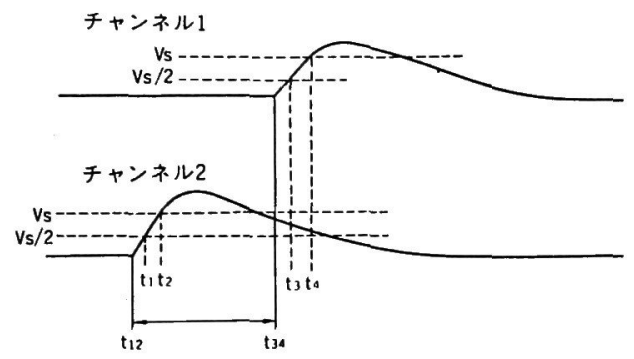

図 5 パルスの立上りの読取り

Fig. 5. Reading method of the point of rise of a pulse.

者による読取り方法に近づけるため，次のような工夫 をした。

図 5 に示すように，あるしきい值 $V_{s}$ を設定し，パ ルスの到達をまずマイコンに入力する。次に，記憶さ れているパルス波形から時間をさかのほっって, $V_{s} / 2$ に相当する時刻を読取る。これら $V_{s}$ と $V_{s} / 2$ の時間 を直線外挿して, 立上り時刻 $t_{12}, t_{34}$ 扔よび時間差 $T$ を算出する。すなわち，

$$
\begin{aligned}
& \dot{t_{12}}=t_{1}-\left(t_{2}-t_{1}\right)=2 t_{1}-t_{2} \\
& t_{34}=2 t_{3}-t_{4} \cdots \cdots \cdots \cdots \cdots \cdots \cdots \cdots \cdots \cdots \cdots \cdots \cdots \cdots \cdots \cdots \cdots \\
& T=t_{34}-t_{12}=2\left(t_{3}-t_{1}\right)-\left(t_{4}-t_{2}\right)
\end{aligned}
$$

（3）自動位置標定器の特性自動位置標定器の 主な特性を表 2 に示す。

測定, 計算, プリントアウトの動作は 10 パルスご とに行われる。1 パルスの測定および計算の処理時間 は約 $300 \mathrm{~ms}$ であり，10パルスのプリントアウトに約 3 秒かかる。従って, 1 パルスの平均測定時間は約 0.6 秒である。これは, 直流電圧課電時の基準放電電 荷(3) が 1 パルス/秒の頻度で発生する放電であること を考えると十分な処理速度である。
表 2 自動標定器の主な特性

Table 2. Major characteristics of the automatic locator.

\begin{tabular}{c|c}
\hline \multicolumn{1}{c|}{ 項 } & \multicolumn{1}{c}{ 目 } \\
\hline 測定可能な放電大きさ & 最小 $50 \mathrm{pc}$ \\
\hline 位置標定の測定誤差 & 約 $50 \mathrm{~m}$ 以内 \\
\hline Iパルスの測定時間 & 約 0.6 秒 \\
\hline
\end{tabular}

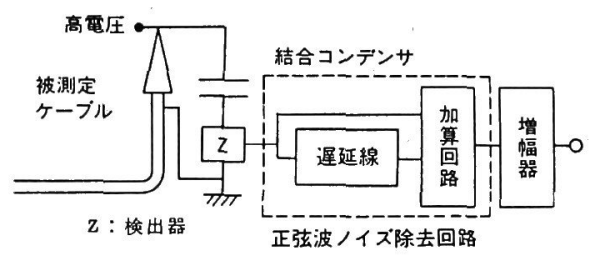

図 6 位相調整によるノイズ除去回路

Fig. 6. Phase-adjusted noise elimination circuit.

〈3·2〉 位相調整（遅延線）による正弦波雑音除去 部分放電測定では雑音除去が重要な課題である。雑 音除去としては平衡法 (バランス法) がよく用いられ る。著者らも，まずそれを試みた。当初は現場測定で も良好な結果が得られたが(4), 雑音の侵入形態が複雑 であり，常に改善できる方法ではなかった。

実測によると雑音波形は正弦波であった。この点に 着目し, 図 6 のように遅延線を用い雑音波形の $1 / 2$ 周 期だけ遅らせた信号と元の信号を加算し，雑音を除去 する方式を開発した ${ }^{(5)}$ 。この遅延線は，0〜0.5 $\mathrm{s}$ の 間で連続的に遅延時間を調整することができる。

〈3・3〉 ジョイントの影響の除去 部分放電の発 生位置標定は通常被測定ケーブルの一端（測定端）で 放電パルスを観測し，その第 1 波と第 2 波の時間差 $T$ を測定している(図 1, 図 2 参照)。

ところが，実布設ケーブルはサージインピーダンス の異なる異種または異径ジョイントを含んでいる場合 が多い。これらのジョイントで，部分放電パルスは反 射し，測定端で第 2 波として検出されることがあり， 測定ミスを起こす危険があった。

そこで，図 3 に示すように被測定ケーブルで発生し た部分放電パルスを遠方端でも検出し，そのパルスを 残り 2 相のうち 1 相（以下，パルス返しケーブルとい う）に注入し，測定端へ戻す方式を開発した。本方式 では測定端で被測定ケーブルからの信号とパルス返し ケーブルからの信号の各々第 1 波を観測し，それから 時間差 $T$ を算出する (図 7 参照)。ジョイントからの 反射波は第 1 波の到達以後に現れるため, 本方式のよ うな第 1 波のみを用いる位置標定法ではジョイントか らの反射波の影響を受けない。 


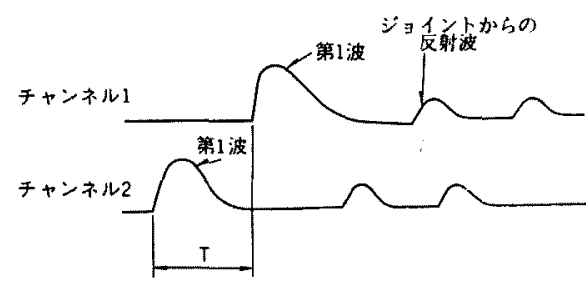

図 7 二相方式に㧈ける時間差の測定例

Fig. 7. Measurement of time difference of two-phase method.

〈3・4〉 パルス減衰の補償と校正方法 パルスの 波高值はケーブル伝搬距離に従って小さくなるため検 出感度が低下する。そこで図 3 に示すように，遠方端 でパルスを検出し，パルス返しケーブルにパルスを注 入する前に増幅する方法を採用した。

この方法を採用するにあたり，パルス検出感度は次 のように設定した。すなうち，被測定ケーブル測定端 に測定したい大きさの校正パルスを注入し，ディジタ ルメモリーCH 1 の検出電圧を注入したパルス波高值 に設定する。次に，同じ大きさの校正パルスを被測定 ケーブル遠方端に注入し， $\mathrm{CH} 2$ の検出電圧をこの波 高值に設定する。 $\mathrm{CH} 1, \mathrm{CH} 2$ とも設定電圧以上であ るパルスについてのみ位置標定を行うょうにプログラ ムする。この校正方法により，被測定ケーブルのいか なる点で発生した，設定パルス以上の部分放電も検出 できることが保証できる。

なお，パルスの検出感度は校正を行う位置により変 化するため, 雑音レベルも変わる。この位置標定方法 では雑音レベルを, パルス検出感度が最低となる点, すなわち湘定端に校正パルスを注入したときの CH 1 のパルス検出感度より算出している。

\section{4. 自動標定器の動作確認試駼}

〈4・1〉 自動標定器による位置標定結果 $A$ 線路 $(22 \mathrm{kVSL}$ ケーブル, 亘長 $1,740 \mathrm{~m})$ において, 図 3 の測定回路を組み、直流電圧 $30 \mathrm{kV}$ を印加した際の 測定結果を図 8 に示す。

同図は $500 \mathrm{pC}$ 以上の部分放電（雑音レベル：250 pC）を湘定後,プリンタによって出力されたもので ある。グラフの上に打出されている数值は, 各々の部 分放電の発生位置 (測定端からの距離) を示し,この 発生位置を頻度グラフ化したものが下のグラフであ る。この線路では，100 200 $\mathrm{m}$ 付近に発生位置が集 中していることがわかる。このように，自動位置標定 器を用いれば，特に操作に熟練した技術を必要とせ ず，測定可能である。

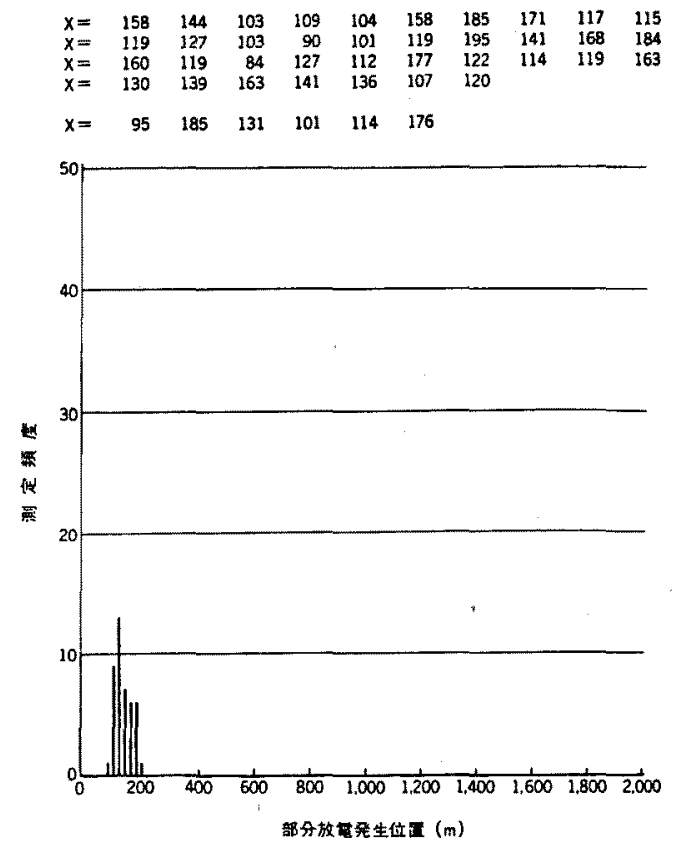

図 8 自動標定器による測定結果

Fig. 8. Results from the automatic locator.

《4-2〉雑音除去効果屋外実験場に打ける模擬 線路 $(22 \mathrm{kVCV}$ ケーブル, 亘長 $335 \mathrm{~m})$ で実際に侵 入してくる雑音で雑音除去効果の確認を行った。模擬 線路の模擬欠宿部に校正パルス $500 \mathrm{pC}$ を注入し，雑 音除去回路を取付けた場合と取付けなかった場合の出 力波形を観測した結果を図 9 に示す。これによると， 約 $250 \mathrm{pC}$ あった雑音が約 $50 \mathrm{pC}$ に低滅されているこ とがわかる。なお，(a)図の正弦波雑音は $1,422 \mathrm{kHZ}$ であり，ラジオノイズである。

〈4・3〉 ジョイントの影響の除去効果 $\quad A$ 線路に おいて, 図 3 に示したパルス返しケーブルを用いず, 図 1 の基本回路に自動標定器を取付け測定した結果を 図 10 に示す。同図も図 8 と同様に $500 \mathrm{pC}$ 以上（雑音 ノイズレベル：250 pC) の部分放電を測定した結果で ある。図 8 と図10を比較すると，両方共 $100 \sim 200 \mathrm{~m}$ の 位置に部分放電パルスが測定されているが，図 10 に は，1,640 m の位置にも多くのパルスが観測される。

$A$ 線路はすべて SL ケーブルであるが，測定端から $83 \mathrm{~m}$ の位置に異径ジョイント $\left(150 \mathrm{~mm}^{2}: 100\right.$ $\left.\mathrm{mm}^{2}\right)$ がある。従って，第 1 波が測定端に達した後， 反射してそのジョイントで再び反射してくると，遠方 端加ら $83 \mathrm{~m}$ の位置，すなわち測定端から $1,657 \mathrm{~m}$ の 位置で部分放電が発生したものと出力される。すなわ ち, 図 10 の $1,640 \mathrm{~m}$ に現れている測定值は, ジョイ 


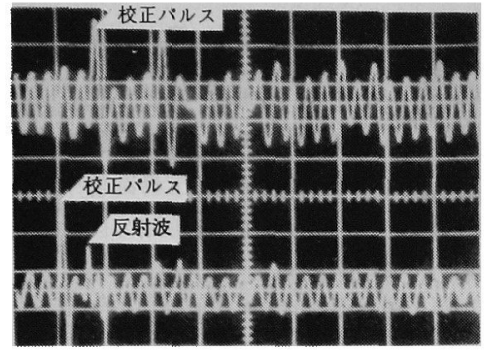

(a) 雑音除去回路なし

$\mathrm{CH} 1: 100 \mathrm{mV} / \mathrm{div}, \mathrm{CH} 2: 40 \mathrm{mV} / \mathrm{div}, 2 \mu \mathrm{s} / \mathrm{div}$

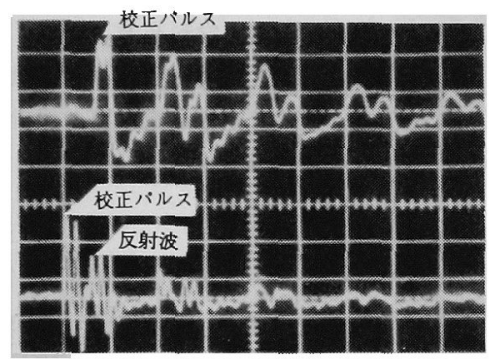

(b) 雑音除去回路あり

$\mathrm{CH} 1: 100 \mathrm{mV} / \mathrm{div}, \mathrm{CH} 2: 40 \mathrm{mV} / \mathrm{div}, 2 \mu \mathrm{s} / \mathrm{div}$ 図 9 雑音除去回路の効果

Fig. 9. Effects of noise elimination circuit.

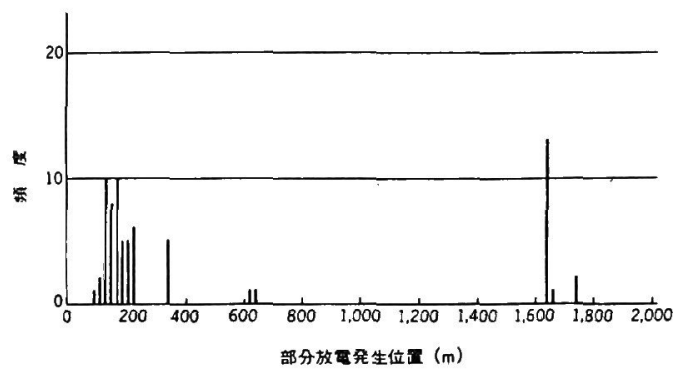

図 10 位置標定結果 (パルス返しケーブル を使用しない場合)

Fig. 10. Results of partial discharge location (not using a pulse return cable).

ントの反射による測定ミスである。これに対して、ジ ヨイントの反射の影響を除去できる二相方式での結果 (図 8) には, 1,657 $\mathrm{m}$ 付近には全く観測結果が現れて おらず，期待どおりの効果が得られた。

〈4・4〉 パルス減衰の補償効果の確認 パルス減 衰の補償効果を確認するため, 従来の位置標定方式に おける第 2 波（図 2 参照）と，今回開発した方法にお けるパルス返しケーブルで検出した第 1 波（図 7 参 照）の検出感度を, 現場にて測定, 比較した。その結 果を表 3 に示す。
表 3 パルス検出感度の比較

Table 3. Comparison of detection sensitirity of partial discharge pulse.

\begin{tabular}{|c|c|c|c|}
\hline \multirow[b]{2}{*}{ 線路 No. } & \multicolumn{2}{|c|}{ パルス感度 $(\mathrm{mv} / 100 \mathrm{pc})$} & \multirow[b]{2}{*}{$\begin{array}{c}\text { パルス感度の比率 } \\
(B) /(A))\end{array}$} \\
\hline & $\begin{array}{l}\text { 従来法における第 } \\
2 \text { 波(A) }\end{array}$ & $\begin{array}{l}\text { パルス返し相から } \\
\text { の第 } 1 \text { 波(B) }\end{array}$ & \\
\hline 1 & 0.80 & 5.2 & 6.5 \\
\hline 2 & 8.0 & 28 & 3.5 \\
\hline 3 & 1.0 & 6.0 & 6.0 \\
\hline 4 & 1.6 & 8.0 & 5.0 \\
\hline 5 & 0.20 & 4.0 & 20 \\
\hline 6 & 1.2 & 10 & 8.3 \\
\hline 7 & 0.80 & 2.0 & 2.5 \\
\hline 8 & 0.80 & 2.4 & 3.0 \\
\hline 9 & 3.2 & 12 & 3.8 \\
\hline 10 & 1.2 & 9.6 & 8.0 \\
\hline
\end{tabular}

同表によると，従来法に扔ける第 2 波の検出感度よ り，パルス返し相から検出した第 1 波が約 2 2 2 倍検 出感度が高くなっており, パルス減衰の補償効果が確 認できた。

\section{5. 自動標定器の現地検証}

位置標定器の精度と信頼性を確認するため, 約 10 回線の線路で現場測定を行った ${ }^{(6)}$ 。現場測定では, 一 つの被測定線路に対し, 両終端から位置標定を行い結 果を比較した。更に, 部分放電が多数発生した箇所を 撤去し, 詳細に調査した(7)。

結果の一例として, $B$ 線路 $(22 \mathrm{kV}, \mathrm{SL}$ ケーブル, 亘長 $1,411 \mathrm{~m}$ ) での測定結果を図 11 に示す。

部分放電位置標定は直流電圧 $30 \mathrm{kV}$ 印加直後掠上 び 3 分後の各々 10 秒行い, 両結果をプリンタに打出 した。部分放電の発生が多かった $200 \mathrm{~m}$ の区間につ いては，撤去後再度部分放電位置標定を行い，その後 更に短く切分け各部の精密な部分放電測定を行った。

同図によると, 両端からの位置標定結果はよく一致 しており, また, 短く切分けた後の部分放電測定結果 共一致している。これらのことより, 自動標定器の信 頼性が確認できたといえる。

\section{6.あとがき}

現地における部分放電位置標定の, 測定の簡素化お よび測定精度向上のため, 新しい位置標定法および自 動部分放電位置標定器を開発した。

（1）自動部分放電位置標定器では，パルス波形の 解析などをマイクロコンピュータで行うため, 測定に 熟練した技術を必要としない。更に, 二相方式の採用 により,ジョイントからの反射による測定ミスをなく すことができた。 


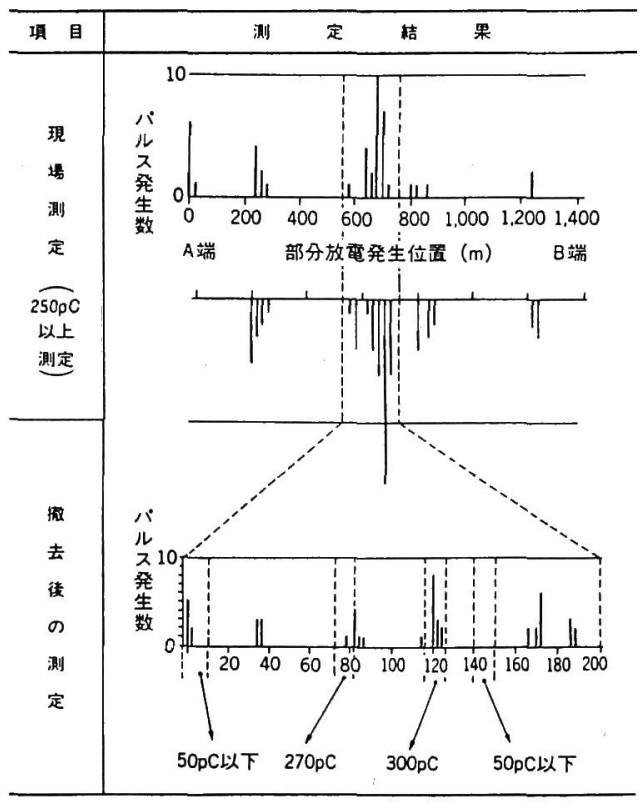

図 11 部分放電位置標定検証試験結果

Fig. 11. Result of comfirmation test for the partial discharge locator.

（2）遅延線を利用した正弦波雑音除去方式の開発 により，雑音レベルを約 $1 / 5$ に抑えることができた。 また, 遠方端でもパルスを検出し, 増幅して送り返す方 式により，測定感度を 2〜20 倍上げることができた。

（3）模擬線路における測定および現場測定を行 い, 開発した部分放電位置標定器が期待どおりに動作 することを確認した。更に, 約 10 回線の線路で現場 測定を行い測定精度と信頼性を確認した。

なお, 本自動位置標定器は自動測定システム ${ }^{(8)} に$ 組込み，現在稼働中である。

(平成 3 年 7 月 16 日受付，同 4 年 1 月 14 日再受付)

\section{文献}

（1）坂口, 他：電カケーブルの部分放電発生位置標定器の改良 (その 2 ), 昭 59 電気学会全大 12,1656

（2）電気学会技術報告（II 部），No.4，No. 51 (昭 43)

（3）電気協同研究，23，No.5，33 (昭 42)

（4）遠藤, 他：「電力ケーブルの部分放電発生位置標定器の開 発」，昭和電線電鏗レビュー，33，No. 2，43（昭 58-12）

（5）坂口, 他：「電力ケーブルの部分放電位置標定器の改良 (そ の2)」, 昭 59 電気学会全大, p. 1656

（6）大野, 他：「部分放電発生位置自動標定器による $22 \mathrm{kV}$ 経 年 $\mathrm{SL}$ ケーブルの劣化調榃結果」, 昭 60 電気学会東京支大, p. 218

（7）小松, 他：「SL ケーブルの部分放電測定による劣化診断」, 昭 63 電気学会全大, No. 11,1776

（8）大野, 他：「自動絶緑測定システムの開発」, 昭 62 同上, No. 12,1784

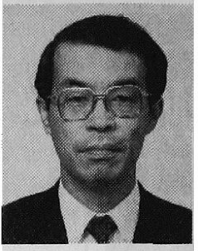

\section{大 野 博 伸 (正員)}

昭和 25 年 2 月 25 日生。 47 年茨城大 学電気工学科卒業。同年 4 月東京電力 (株) 入社。現在工務部地中線課長。主と して, 地中送電線路の設計, 建設, 保守 業務に従事し，現在に至る。

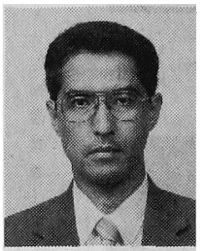

\section{勝 田 銀 造 （正員）}

昭和 30 年 8 月 30 日生。 53 年東京電 機大学電気工学科卒業。同年 4 月東京電 力 (株) 入社。現在工務部地中線課副長。 主として, 地中送電線路の設計, 建設, 保守業務に従事し，現在に至る。

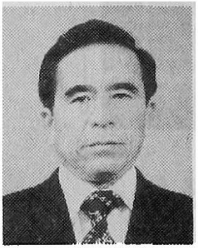

坂 口隆 二（非会員）

昭和 6 年 11 月 30 日生。 27 年新潟県 立六日町高校普通科卒業。同年 4 月東京 電力 (株) 入社。主として, 地中送電線路 の建設, 保守業務に従事し, 平成元年 9 月同社を退社。現在, 東京電設サービス(株)北支社工務部 地中線課長 (総括)。

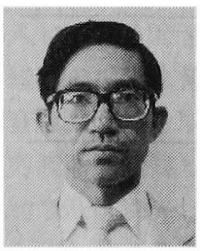

\section{海老沼 康 光（正員）}

昭和 22 年 10 月 5 日生。 47 年東京都 立大学大学院修士課程修了。同年昭和電 線電纜(株) 入社。高圧ケーブルの絶縁設 計と絶緑診断方法の開発に従事, 現在, 高電圧研究室長。平成元年電気学会論文賞受賞。

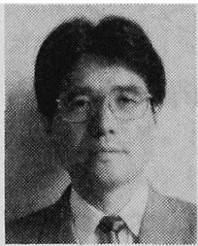

\section{佐々木 伸 洋（正員）}

昭和 24 年 11 月 19 日生。 43 年宮城県 立米谷工業高校卒業。同年 4 月昭和電線 電纜(株)入社。主として，電力ケープル の保守点検および監視システムの開発, 設計に従事し, 現在, 線路システム研究室主任。

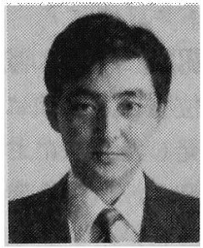

永岡 明（正員）

昭和 35 年 6 月 4 日生。 58 年九州工業 大学電気工学科卒業。同年 4 月昭和電線 電纜(株)入社。主として，電力ケーブル の絶縁診断方法の研究開発に従事し, 現 在, 電力技術第一課主任。 